\title{
SYNTHESIS OF SOME PENTACOORDINATED GERMANIUM COMPOUNDS
}

\author{
Xue Tao Feng, Sheng Cui, Ru Zhen Cao and Lun Zu Liu* \\ Institute of Elemento-Organic Chemistry, Nankai University, \\ Tianjin 300071, People's Republic of China
}

\begin{abstract}
The 1,1-dichloro-1,2-germathia-3-cyclopentanones react with diethyl N,N-bis(2hydroxyethyl)aminomethylphosphonate in the presence of triethylamine to afford the pentacoordinated germanium compounds. The reaction of dimethylgermanium dibromide with the sodium salt of phenyl bis-(2-hydroxyethyl) phosphine produced a novel type of pentacoordinated germanium compound. The transannular interaction in these compounds is discussed in terms of acidity of the germanium and basicity of the nitrogen or phosphorus.
\end{abstract}

\section{INTRODUCTION}

The synthesis of pentacoordinated germanium compounds featuring a $\mathrm{N} \rightarrow \mathrm{Ge}$ linkage has recently attracted particular attention, not only owing to their specific biological activity, but also because of their unique structures and chemical properties ${ }^{[1]}$. Of interest in systems of these compounds is the characterization of the transannular interaction between germanium and nitrogen. However, which factor influences the transannulation is less well-understood. Generally, the degree of transannular interaction depends on the basicity of nitrogen and the acidity of germanium. Thus the donor-acceptor relationship will merit further investigation.

\section{RESULTS AND DISCUSSION}

We have previously reported ${ }^{[2]}$ that the reaction of germanium sesquioxides 1 with diethyl $\mathrm{N}, \mathrm{N}$-bis-(2-hydroxyethyl)aminomethylphosphonate 2 afforded the pentacoordinated germanium compounds 3 , characterized by the presence of a $\mathrm{N} \rightarrow \mathrm{Ge}$ bond.
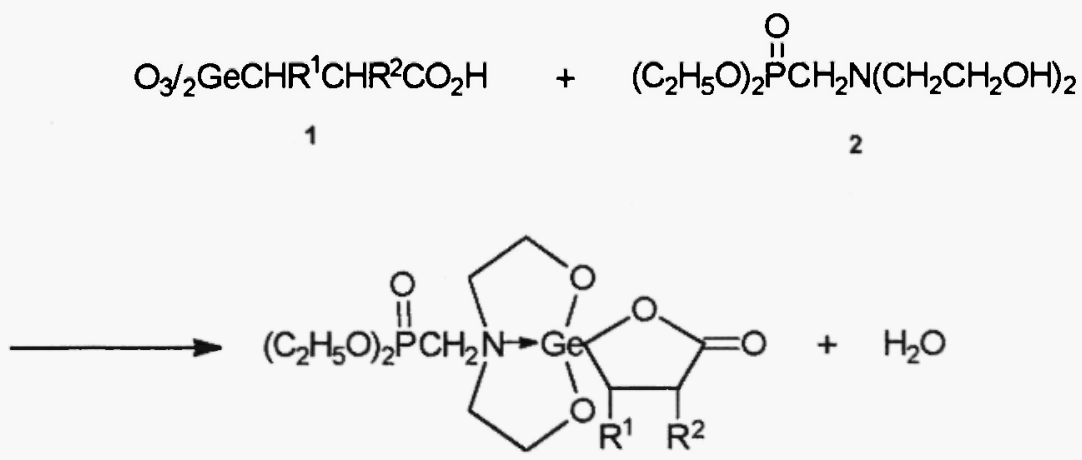
It should also be recognized that the electrophilic phosphoryl group, which is directly bonded to the nitrogen in the compounds 3 , decreases the basicity of the nitrogen so that it inhibits the formation of $\mathrm{N} \rightarrow \mathrm{Ge}$ bond $^{[2]}$. To explore further the influence of the acidity of germanium on the transannulation, we synthesized the following compounds, 5 and 6 .

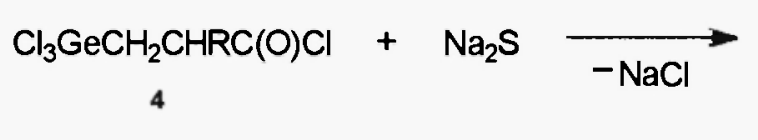<smiles>[R]C1C[Ge](Cl)(Cl)SC1=O</smiles>

5

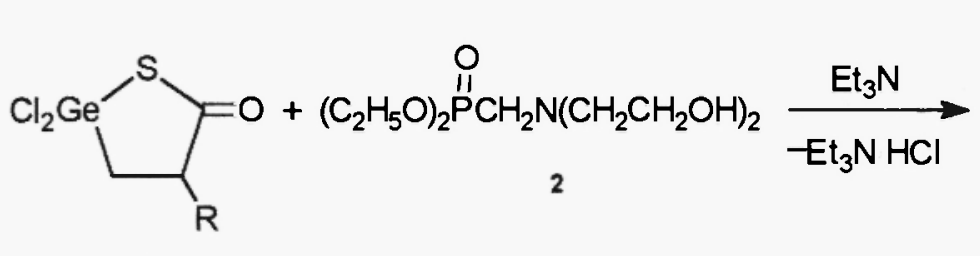
5
a: $\mathrm{R}=\mathrm{H}$;
b: $\mathrm{R}=\mathrm{CH}_{3}$.

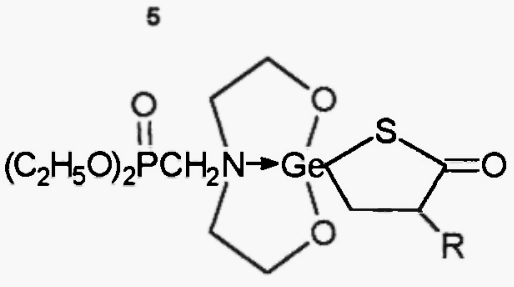

After work-up, the reaction mixture must be stored in the refrigerator over a period of weeks to give a solid, compounds 6 . This contrasts with the rapid and excellent transannulation of the compounds 3. Moreover, the compounds 6 exhibit less thermal and hydrolytic stabilities in comparison with the compounds 3 . The difference could be attributed to the stronger acidity of the germanium in 3 than in $\mathbf{6}$. The reaction of 5 with diethoxy N,N-bis(2-hydroxyethyl)phosphamide 7 also has not been successful. If the alkyl groups bonded to the germanium, it might be expected that the reaction of 7 with 8 will be realized ${ }^{[3]}$.

$$
\underset{7}{\left(\mathrm{C}_{2} \mathrm{H}_{5} \mathrm{O}\right)_{2} \stackrel{\mathrm{PN}}{\mathrm{P}}\left(\mathrm{CH}_{2} \mathrm{CH}_{2} \mathrm{OH}\right)_{2}}+\underset{8}{\mathrm{Br} r_{2} \mathrm{Ge}\left(\mathrm{CH}_{3}\right)_{2}} \stackrel{-\underset{\mathrm{Et}_{3} \mathrm{~N}}{\longrightarrow}}{\underset{-\mathrm{Et}_{3} \mathrm{~N} \cdot \mathrm{HBr}}{\longrightarrow}}
$$

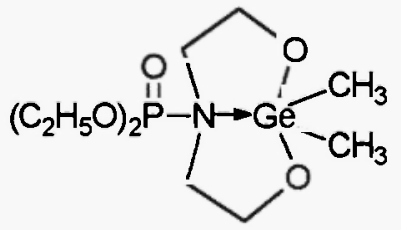

9

We also obtained an interesting result in studying the reactivity of 10 with 8 . As might be expected, the germanium in $\mathbf{1 1}$ is sufficiently acidic to induce the transannulation between germanium and phosphorus to form a $\mathrm{P} \rightarrow \mathrm{Ge}$ bond.

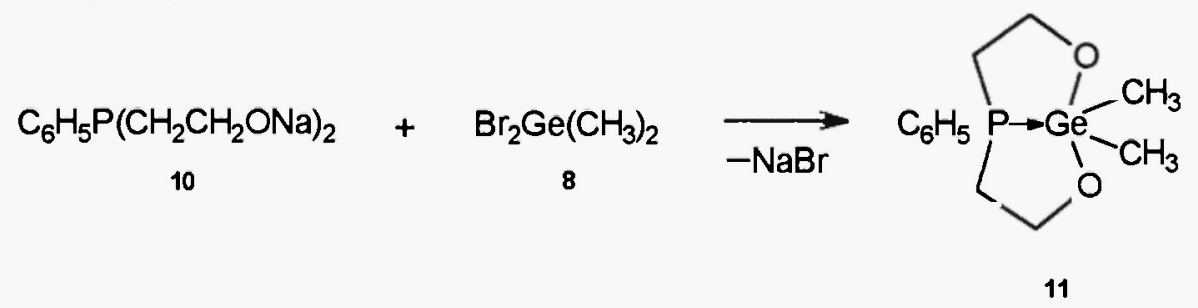

Although the compound $\mathbf{1 1}$ is too unstable to perform an X-ray diffraction analysis, its structure has been characterized by NMR criteria. The ${ }^{31} \mathrm{P}$ chemical shift for $11(43.34 \mathrm{ppm})$ is considerably lower that of $10(-39.57 \mathrm{ppm})$ and this shift moves downfield to $82.91 \mathrm{ppm}$, implying the presence of 
transannular $\mathrm{P} \rightarrow \mathrm{Ge}$ interaction. In contrast, when 10 reacts with $5,{ }^{31} \mathrm{P}$ NMR spectroscopy reveals no evidence for any transannular $P \rightarrow G e$ interaction.

\section{EXPERIMENTAL}

Preparation of 5

To a stirred solution of trichlorogermyl propionyl chlorides $4^{i \vec{i}}(40 \mathrm{mmol})$ in absolute acetonitrile $(80 \mathrm{~mL})$ was added anhydrous sodium sulfide $(50 \mathrm{mmol})$ at room temperature. The reaction mixture was allowed to stir for 14 hours at $30^{\circ} \mathrm{C}$. The sodium chloride that had formed was removed by filtration, and the filtrate was concentrated at reduced pressure to give a viscous liquid, which then was distilled in vacuum to yield 5 .

5a: b.p $118-120^{\circ} \mathrm{C} / 10 \mathrm{mmg}$, yield $66 \%{ }^{1} \mathrm{H} \quad \mathrm{NMR}\left(\mathrm{CDCl}_{3}\right): 2.21\left(\mathrm{t}, 2 \mathrm{H},{ }^{3} \mathrm{~J}_{\mathrm{HH}} 7.2 \mathrm{~Hz}\right), 3.35(\mathrm{t}, 2 \mathrm{H}$, ${ }^{3} \mathrm{~J}_{\mathrm{HH}} 7.2 \mathrm{~Hz}$ ). Anal. Calcd. for $\mathrm{C}_{3} \mathrm{H}_{4} \mathrm{Cl}_{2} \mathrm{GeOS}$ : $\mathrm{C}, 15.54 ; \mathrm{H}, 1.73$. Found: $\mathrm{C}, 15.46 ; \mathrm{H}_{1} 1.84$.

5b: b.p 134-136/4mmg, yield 59\%. ${ }^{1} \mathrm{H} N M R\left(\mathrm{CDCl}_{3}\right): 1.40\left(\mathrm{~d}, 3 \mathrm{H},{ }^{3} \mathrm{~J}_{\mathrm{HH}} 7.2 \mathrm{~Hz}\right), 1.96-2.64(\mathrm{~m}, 2 \mathrm{H})$, 2.94-3.28(m,1H). Anal. Calcd. for $\mathrm{C}_{4} \mathrm{H}_{6} \mathrm{Cl}_{2}$ GeOS: $\mathrm{C}, 19.54 ; \mathrm{H}, 2.44$. Found: $\mathrm{C}, 19.48 ; \mathrm{H}, 2.46$.

Preparation of 6

To a stirred solution of diethyl N,N-bis(2-hydroxyethyl)aminomethylphosphonate $2^{[2]}(2.5 \mathrm{mmol})$ and triethylamine $(5 \mathrm{mmol})$ in absolute $\operatorname{THF}(20 \mathrm{~mL})$ was added dropwise a solution of $5(2.5 \mathrm{mmol})$ in $\operatorname{THF}(5 \mathrm{~mL})$ at $-10^{\circ} \mathrm{C}$. After addition, the reaction mixture was allowed to warm up to room temperature and stirred for 8-12 additional hours. The triethylamine hydrochloride that had formed was filtered out, and the filtrate was concentrated in vacuum to give a sticky material, which was washed with petroleum ether to isolate a solid. The solid was recrystallized from dichloromethanepetroleum ether(4:1), then kept in refrigerator for several weeks to yield the desired products 6 .

6a: m.p $121-122^{\circ} \mathrm{C}$, yield $72.1 \%$. ${ }^{1} \mathrm{H} \mathrm{NMR}\left(\mathrm{CDCl}_{3}\right)$ : $1.31\left(\mathrm{t}, 6 \mathrm{H},{ }^{3} \mathrm{~J}_{\mathrm{HH}} 7.2 \mathrm{~Hz}\right), 1.60\left(\mathrm{t}, 2 \mathrm{H},{ }^{3} \mathrm{~J}_{\mathrm{HH}} 7.0 \mathrm{~Hz}\right)$, $2.56\left(\mathrm{t}, 2 \mathrm{H},{ }^{3} \mathrm{~J}_{\mathrm{HH}} 7.0 \mathrm{~Hz}\right), 2.94\left(\mathrm{~d}, 2 \mathrm{H},{ }^{2} \mathrm{~J}_{\mathrm{HP}} 10.8 \mathrm{~Hz}\right), 3.04-3.24(\mathrm{~m}, 4 \mathrm{H}), 3.74-4.01(\mathrm{~m}, 4 \mathrm{H}), 3.96-4.24(\mathrm{~m}$, 4H). $\quad{ }^{31} \mathrm{P} \mathrm{NMR}\left(\mathrm{CDCl}_{3}\right): 20.05$. Anal. Calcd.for $\mathrm{C}_{12} \mathrm{H}_{24} \mathrm{NGeO}_{6} \mathrm{PS}: \mathrm{C}, 34.82 ; \mathrm{H}, 5.80 ; \mathrm{N}, 3.38$. Found: C, $34.71 ; \mathrm{H}, 5.98 ; \mathrm{N}, 3.59$.

6b: m.p $100-101^{\circ} \mathrm{C}$, yield $69.1 \% .{ }^{1} \mathrm{H}$ NMR $\left(\mathrm{CDCl}_{3}\right): 1.14\left(\mathrm{~d}, 3 \mathrm{H}^{3}{ }^{3} \mathrm{~J}_{\mathrm{HH}} 7.2 \mathrm{~Hz}\right), 1.33\left(\mathrm{t}, 6 \mathrm{H},{ }^{3} \mathrm{~J}_{\mathrm{HH}} 7.2 \mathrm{~Hz}\right)$, 1.56-1.72(m,2H), 2.00-2.17(m,1H), 2.80-3.00(m,4H), 3.24(d, $\left.2 \mathrm{H},{ }^{2} \mathrm{~J}_{\mathrm{HH}} 10.8 \mathrm{~Hz}\right), 3.80-3.90(\mathrm{~m}, 4 \mathrm{H})$, 4.12-4.19(m,4H). ${ }^{31} \mathrm{P} \mathrm{NMR}\left(\mathrm{CDCl}_{3}\right):$ 21.66. Anal. Calcd. for $\mathrm{C}_{13} \mathrm{H}_{26} \mathrm{NGeO}_{6} \mathrm{PS}: \mathrm{C}, 36.48 ; \mathrm{H}, 6.08 ; \mathrm{N}$, 3.27. Found: $\mathrm{C}, 36.52 ; \mathrm{H}, 6.18 ; \mathrm{N}, 3.41$.

\section{Preapration of 11}

To a suspention of the sodium salt of phenyl bis(2-hydroxyethyl)phosphine ${ }^{[5]}(2.5 \mathrm{mmol})$ in $\mathrm{DMF}(30 \mathrm{~mL})$ was added a solution of dimethylgermanium dibromide ${ }^{[6]}(2.5 \mathrm{mmol})$ in DMF $(5 \mathrm{~mL})$ at room temperature in a nitrogen atmosphere.After addition, the reaction mixture was stirred for 24 hours. The solvent was removed in vacuum to give a solid, which was dissolved in trichloromethane $(30 \mathrm{~mL})$, and filtered. The filtrate was concentrated in vacuum, and the residue was purified by column chromatography on silica gel using ethyl acetate as the eluent to give a white soid, i.e. compound 11. Immediately, the compound 11 was detected by NMR spectroscopy and elemental analysis, because the compound 11 in solid state is unstable. Yield $58 \%$. ${ }^{31} \mathrm{P}$ $\operatorname{NMR}\left(\mathrm{CDCl}_{3}\right): 43.34 .{ }^{1} \mathrm{H} \mathrm{NMR}\left(\mathrm{CDCl}_{3}\right): 0.045(\mathrm{~s}, 6 \mathrm{H}), 2.15\left(\mathrm{t}, 4 \mathrm{H},{ }^{3} \mathrm{~J}_{\mathrm{HH}} 6.5 \mathrm{~Hz}\right), 3.78\left(\mathrm{dt}, 4 \mathrm{H},{ }^{3} \mathrm{~J}_{\mathrm{HH}} 6.2 \mathrm{~Hz}\right.$, 
$\left.{ }^{2} \mathrm{~J}_{\mathrm{HP}} 11.00 \mathrm{~Hz}\right), 7.35(\mathrm{~m}, 5 \mathrm{H})$. Anal. calcd. for $\mathrm{C}_{12} \mathrm{H}_{19} \mathrm{GeO}_{2} \mathrm{P}: \mathrm{C}, 48.23 ; \mathrm{H}, 6.36$. Found: $\mathrm{C}, 48.18 ; \mathrm{H}$, 6.48 .

\section{ACKNOWLEDGEMENT}

This research has been supported by the State Commission of Science and Technology of China.

\section{REFERENCES}

[1]N. Kakimoto, K. Sato, T.Takada, M. Akiba, Heterocycles, 26(2), 347(1987); N. A. Viktorov, S.N. Gurkova, A.I. Gusev, T.K. Gar, V.F. Mironov, Metalloorg. Khim., 1(3),715(1988): Chem. Abstr., 111, 125617(1989).

[2]R.Y. Chen, L. Z. Liu, Z.B. Zhang, Heteroatom Chem., 6(6), 503(1995).

[3]R. Z. Cao, X. D. Shi, L.Z. Liu, unpublished.

[4]H. M. Huang, Y.Z.Li, S.E.Hao, Y.P.Wang, Gaodeng Xuexiao Huaxue Xuebao, 11(11), 1295(1990): Chem. Abstr.,114, 164374(1991).

[5]I. Hechenbleikner, W. P. Enlow, Ger. Offen., 2601520(1976): Chem. Abstr., 85, 192883(1976).

[6]V. F. Mironov, A. L. Kravchenko, Izv. Akad. Nauk SSSR, Ser. Khim., 6, 1026(1965): Chem. Abstr., 63,8392(1965).

Received: November 28, 1996 - Accepted: December 6, 1996 Accepted in revised camera-ready format: January 6, 1997 